\title{
SURVEY AND CO-DESIGN THE URBAN LANDSCAPE. INNOVATIVE DIGITAL PATH FOR PERCEPTION ANALYSIS AND DATA-DRIVEN PROJECT
}

\author{
F. Bianconi ${ }^{1}$, M. Filippucci ${ }^{2}$, M. Seccaroni ${ }^{3}$ \\ ${ }^{1}$ Università degli Studi di Perugia, Perugia, Italy, fabio.bianconi@unipg.it, \\ ${ }^{2}$ Università degli Studi di Perugia, Perugia, Italy, marco.filippucci@unipg.it \\ ${ }^{3}$ Università degli Studi di Perugia, Perugia, Italy, marco.seccaroni@gmail.com*
}

\section{Commission II, WG II/8}

KEY WORDS: Landscape, Survey, Perception, Eye-tracking, EEG, Cultural heritage; Data Driven Design, Codesign

\begin{abstract}
The research presents the participatory processes implemented using Eye-track and EEG to analyse and "survey" the landscape, the immaterial relation that determines the quality of places. If it is always feasible to measure quantities, it is more complex to bring out data and interpretations on the values of places. This path based on the centrality of vision, it focuses on the possibility of detecting through biosensors what attracts the eye most, but also on the effect of vision of this on man. By combining these instruments and their data, it is possible to associate the observer's staring with the sensations he feels, thus explicitly explaining the concept of imageability expressed by Kevin Lynch, it is possible to individuate precisely which elements of the urban space attract the observer and what kind of status arouse in him.
\end{abstract}

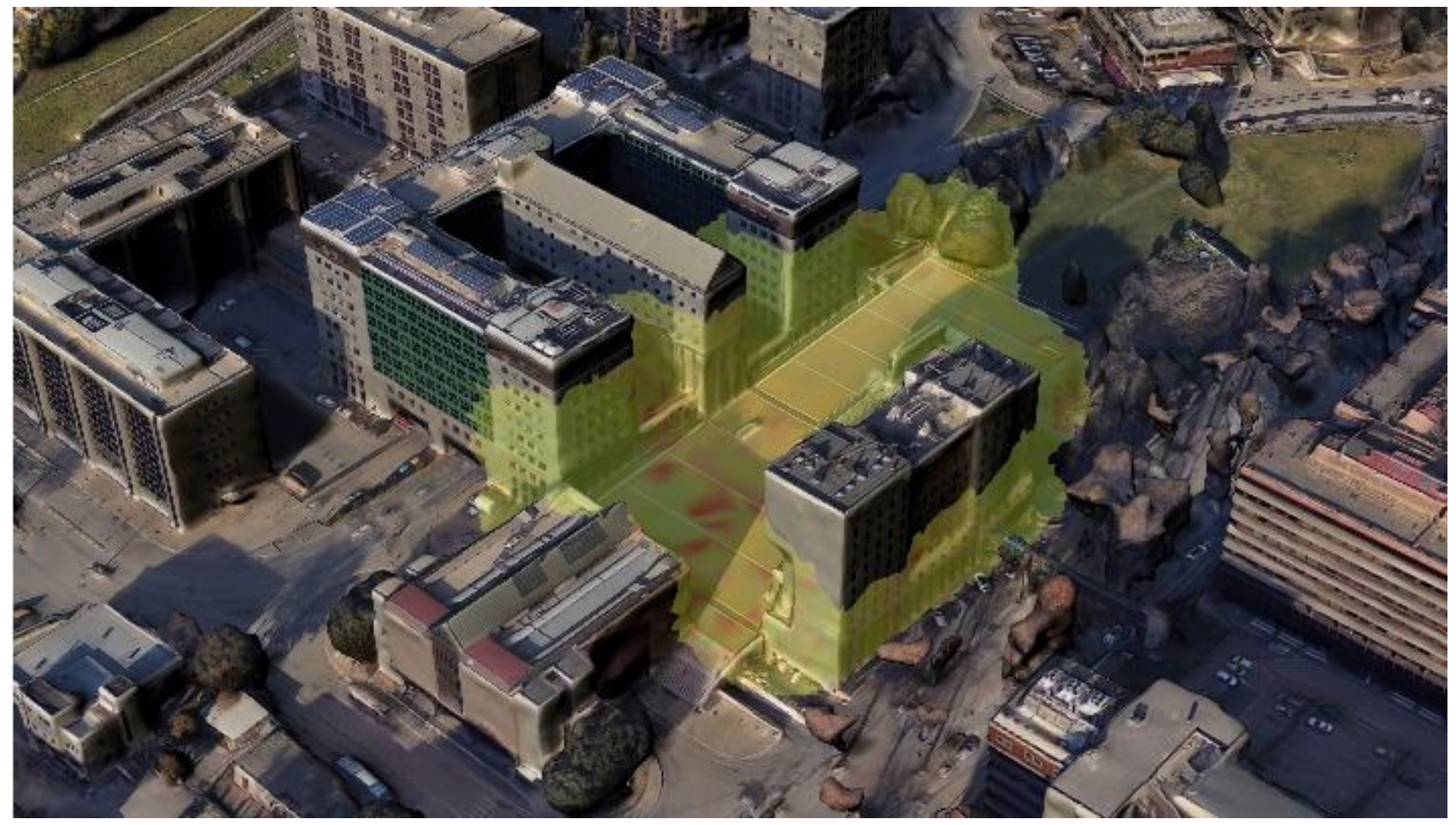

Figure 1 - Representing perception: mesh with the value attribute calculated through the circumplex model.

\section{INTRODUCTION}

Every day more, landscape question becomes one of the themes more debated in academic and political contexts. Everyone wants to preserve landscape but it is not clear what the real subject of their interest is.

The European Landscape Convention defines: "landscape means an area, as perceived by people, whose character is the result of the interaction of natural and/or human factors ...the expression of the diversity of their shared cultural and natural heritage, and a foundation of their identity ". The idea of landscape closely linked to perception, to vision and to those elements that structure the processes of identity construction.

It is possible to extend Kant's philosophic considerations reported in his "Critique of Judgment" (1790), where he asserts that landscape shall not be simply judged as beautiful nor sublime, but rather more perceived as a state of mind. It is possible to "distinguish two styles of perception: one is pragmatic

\footnotetext{
* Corresponding author
} 
and action-oriented, the other is aesthetic and affect-oriented"... in a "cognitive-semiotic theory of conceptual organization and semantic integration in general".... "both the meaning structures found in art and the surplus meanings of things, their 'connotations' are based on non-integrated structures that tend to be integrated on higher levels of mental architecture. The emphatic splitting of experienced situational meaning into two mutually mapping mental spaces - a content space and an expression space - which is characteristic of the phenomenology of works of art and other aesthetically perceived objects, is due to this phenomenon of unintegrated surplus structures" (Brandt, 2006)

In this regard it is possible to understand how the theme, especially if declined in the European city, rich in stratifications and signs, opens to reflect on how the community who lives them can really understand their value, but also creatively participate in protecting and enhance them (Norberg-Schulz, 1992), exploiting also the capabilities of the new digital tools.

The research presents the participatory processes implemented using Eye-track and EEG to analyse and "detect" the landscape, the immaterial relation that determines the quality of places. Such means, up to a recent past, were the prerogative of medical disciplines because of their cost and of the lack of portability. Today they work for marketing purposes, while their use is innovative to understand the public space and as tools for codesigning.

The research tackles the challenge of quality survey (Bianconi and Filippucci, 2018a): if it is always feasible to measure quantities, it is more complex to bring out data and interpretations on the values of places. This path is based on the centrality of vision (Kepes and Chiaia, 1990), the possibility of detecting through biosensors what attracts the eye most, but also the effect of vision of this on man. By combining biosensors, it is possible to associate the observer's staring with the sensations he feels, thus explicitly explaining the concept of imageability expressed by Kevin Lynch (Lynch, 1960), it is possible to individuate precisely which elements of the urban space attract the observer and what kind of status arouse in him.

Through this methodology with a statistical sample, it is possible to identify on average which elements people perceive and which sensations they cause in them. In this way, it is possible to pursue an analysis aimed at a heuristic research for higher quality, with people who simultaneously acquire awareness of the value of their goods (Settis, 2014).

It is therefore possible to set up a co-planning of urban spaces, focused on meanings and not on signs, a specific competence of designers that will not be delegated to a sort of popular jury. The path, however, wants to identify empirically but with a scientific basis and a concrete analyticity in order to intervene effectively, which are the critical issues of the environments and which are the elements of greatest interest to valorise. From the analysis of the results, in fact, it is possible to individuate urban space detractors and the use and placement of urban furnishings, those that generate a negative emotional state. The path can become a paradigmatic example of wayfinding (Belardi and Bianconi, 2012), supported by digital instruments (Bianconi et al., 2019), in a participatory approach in the co-design of public spaces (Bianconi and Filippucci, 2017a). It is about educating the vision (Arnheim, 1986), redefining the centrality of the attention, which is the base of the care of places, but also the definition of the role of the community in protecting and enhancing the cultural heritage.

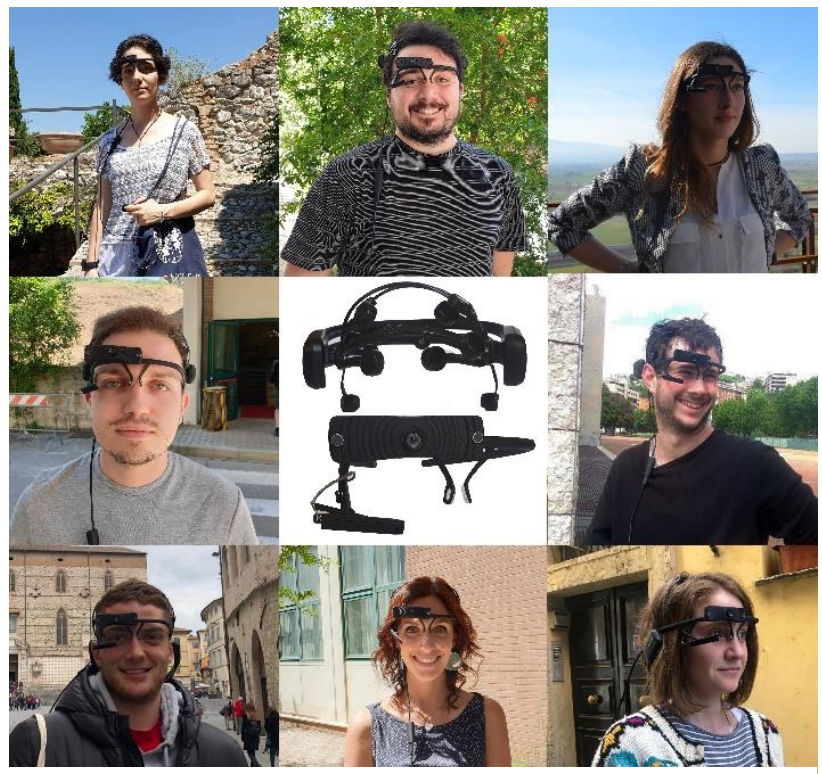

Figure 2 - Survey campaigns and testers with EEG, Eye-tracker and GPS.

\section{MAIN BODY}

\subsection{The research themes}

The research project aims to innovate the approach to the design of urban landscape and public spaces, finalized to increase human health and wellbeing in an intersection of solutions inherent social, cultural, digital and nature-based innovations.

In the centrality of human factor (Sanders and McCormick, 1987), new instruments and methodologies will be developed to examine a real environment, to value the future transformations, to identify and maximize the effects of the environment for man's psychophysical well-being and to valorise the impact of interventions.

Through an interdisciplinary approach and by using new digital tools, the research promotes a redrawing of urban spaces from a perceptive point of view in relation with welfare, in order to analyse strategies for the mitigation of social exclusion and marginalization. Because space shapes our life (Sarah Williams Goldhagen, 2017). It could have a good or a negative effect, but it cannot be neutral and sometimes it contributes to psychophysical illnesses. The design of these public spaces too often is not directly addressed to citizen health (Millennium Ecosystem Assessment, 2005) and well-being (Bechtel and Churchman, 2002), also because there is no methodology to analyse and evaluate the effects of the solutions, a central data to promote a sustainable and welfare design and a participated development of the place.

In the last 20 years the research on health determinant factors clearly shifted the attention to the social dimension of the individual's life (Badland and Pearce, 2019; Byrne et al., 2014; Carmichael, 2019; Corburn, 2004; House et al., 2007; Jackson L, 2003; Konstantinos Tzoulasa et al., 2007; Lee AC. Maheswaran R. and Lee A.C.K., 2011; Leeuw, 1999; M.C. et al., 2018; Schram-Bijkerk et al., 2018). Regarding the overall objective, the proposal wants to test new design strategies, new instruments and methodologies to examine a real environment, to value its future transformations, to identify and maximize the effects of the environment for man's psychophysical well-being. 


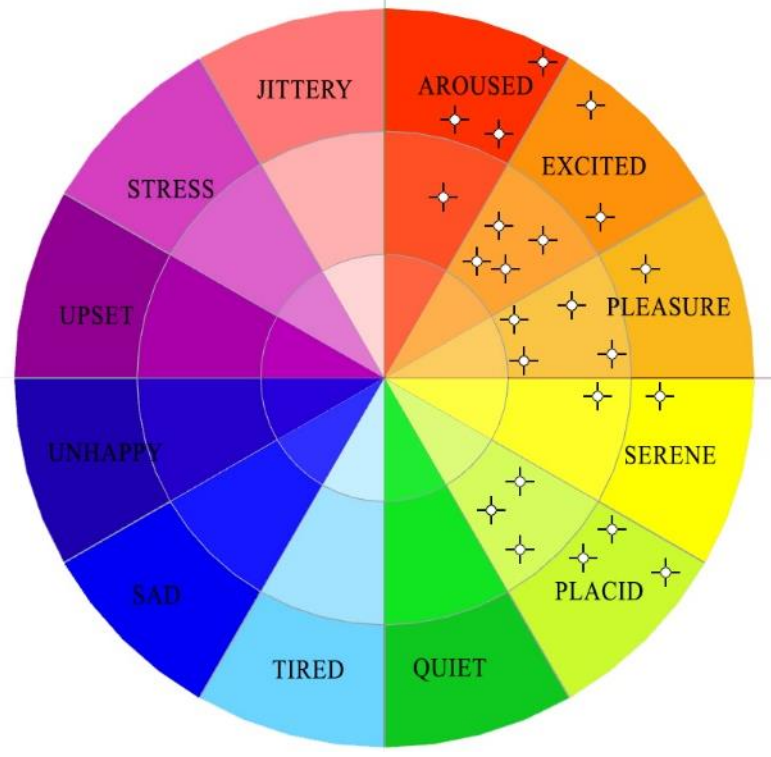

Figure 3 -The circumplex model 12-PAC with a tripartite division according to the intensity of the emotion, at the center the neutral value and the arrangement of some points related to a survey as a function of the two cognitive states.

In this way, the study defines a methodology to analyse public places impacts, in a multidisciplinary way, in health and wellbeing, surveying physical aspects of the city and the citizen behaviour of spaces.

Contemporary cities are conditioned by the modern movement, which pursuing an ideal of aesthetics due solely to functionalism, it made anonymous cities (Appadurai, 1996). Very similar buildings cannot create a figurability (Schultz, 1987), i.e. the quality that gives a physical object a high probability of evoking a vigorous image in every observer.

This contemporary image of the city (Fabio. Bianconi and Filippucci, 2019) underlines rather the relation of modernization which is typical of a widespread urban landscape, and which becomes ever more complex until it reaches its maximum level in the Nineteenth century, due to the conflicts inherent in its development (Appadurai, 1996). Within the city itself, in the wake of the victory of a business-oriented mentality, the built-up environment has undergone a change resulting in the multiplication of signals (Venturi et al., 1977) that imposes a multiplicity of space-time attractors (Appleyard et al., 1966) in a dynamic equilibria (Arnheim, 1965) that changes the face of the city. Urban landscape (Cullen, 1961) born in the reading activity, in the process of transforming the perceived data into patterns and meanings (Jencks, 1969). Representation becomes a transposition of sensible elements in intellectual synthesis, "it is never a given space but a built space" (Panofsky, 1927), where from every point of the space, equal constructions are possible to be built. Identify cannot be separated from identifying: recognisability allows the creation of a urban geography (Larkham and Short, 2006) and a psychogeography (Coverley, 2018) to emerge where the value of the sign (Debord, 1958), central in both perception and in the subsequent design phase, which is substance of connections between semiology and urban plan (Barthes, 1967) .

In this context, the public spaces represent a central paradigm of the historic urban landscape, as places intended to condense meanings. In particular, the public space (Francis et al., 2012; Gehl, 2007; Gehl and Gemzøe, 2003; Gehl and Svarre, 2013; Goheen, 1998) intended as a place where people of social groups, various cultural and demographic, meet and enter into different relations, a space where the public life is centred on communication (Castells, 2008) and vision (Friedman, 1972). The parameters (Ewing et al., 2013) that define spaces are the legibility, the easy interpretation of the surrounding environment (Lynch, 1984), the mystery, the opportunity to obtain additional information through the exploration (Debord, 2006), the intimacy and refuge, the ease of finding a shelter (Pallasmaa, 1994).

A different attention to the design can change the sense of the place for all (Norberg Schulz, 1979), but also the attention to the signposting and architectonic solutions of urban wayfinding (Bechtel and Churchman, 2002; Bianconi et al., 2019; Meng and Zhang, 2012). The idea of public space, in the ordinary usage is completely changed compared to the past, it is the identification of space and meeting that breaks the outskirts of the "analogue city" theorized by Aldo Rossi (Rossi et al., 1976). For many psychologists, the attractiveness of a public space is commensurate with its ability to see others as well as to be seen and to freely express themselves (Gehl, 2011). The public space holds the image of the city (Torelli, 1997) and it wants to focus on those aspects related to the memory of the visitors and of the consciousness of citizens, who are the keepers of their community's values (Szondi and Mendelsohn, 1978).

The issue inheres the measure of perception. "Man is mainly a visual animal, and more than the $50 \%$ of his brain neurons respond to this sensorial incoming" (Maffei, 2007). Immaterial data are the real theme of virtual modeling, those elements that explain and describe in a different way what is observed (Bianconi and Filippucci, 2017b; Filippucci et al., 2016). The visualization of the intangible data allows to fully understanding the environment or the observed object (Bianconi et al., 2019; Gaulon et al., 2017; Remondino et al., 2009). The widely discussed theme of perception (Ancona, 1970; Arnheim, 1965, 1986; Bianconi and Filippucci, 2018b; Fabio Bianconi and Filippucci, 2019; Filippucci, 2013; Gibson, 2014; Gogel and Tietz, 1977; Gregory, 1998; Ramachandran, 1990) thus finds a new life in the field of neuroscience (Pinotti and Lucignani, 2007), which are linked to the logics of neuro-marketing (Berčík et al., 2016; Giraldi et al., 2017; Jordao et al., 2017; Lahmiri, 2018; Oliveira, 2014; Oliveira et al., 2014; Oliviera and Giraldi, 2017; Onay, 2016; Sloan, 2015) used also for urban landscape and public space.

Data are the petroleum of the future, but their real value emerges when they offer an interpretation of the reality, to understand the future transformation. As the MIT professor Alex Pentland affirms, "Moving to a data-driven society will be a challenge. In a world of unlimited data, even the scientific method as we typically use it no longer works: there are so many potential connections that our standard statistical tools often generate nonsense results. The standard scientific approach gives us good results when the hypothesis is clear and the data are designed to answer the question. But in the messy complexity of large-scale social systems, there are often thousands of reasonable hypotheses; it is impossible to tune the data to all of them at once. Therefore, in this new era, we will need to manage our society in a new way. We have to begin testing connections in the real world far earlier and more frequently than we ever have before. We need to construct "living labs" in which we can test our ideas for building data-driven societies" (Pentland, 2013) .

The study of human brain responses to sensations and stimuli stands as fundamental to select data as a function of their impact. It is a "cognitive heuristic" based on simple, rapid, but very effective schemes for evaluating transformation processes of data in information and the information itself in partial knowledge, to address complex situations through simpler problems (Marewski et al., 2010). 
It is significant to note how the user becomes the leading actor, transcribed in the myth of the "consumer-actor" (Codeluppi, 2011), in the creation and dissemination of data, producing an enormous amount of information that becomes significant of trends and developments. If objects are smart and able to communicate, even the individual, in his activities, assumes the paradox of being subject and object of interest, the one who produces data that allows him to describe it, fundamental for marketing. The interest in this production of information is increasingly leading to move from the Internet of Things to the Internet of People (Berrocal et al., 2015; Conti et al., 2017, 2012; Florido et al., 2018; Rajah and Lim, 2018). It is a consequential condition for a greater convergence between the virtual world and the physical environment (Conti et al., 2012), where the digital does not lead to dreamlike engulfment of machines on man, but vice versa is directed more and more to put the person at the center (Anderson, 2002; Anderson et al., 2006; Buchanan, 2002; Cakir, 2011; Srivastava et al., 2012).

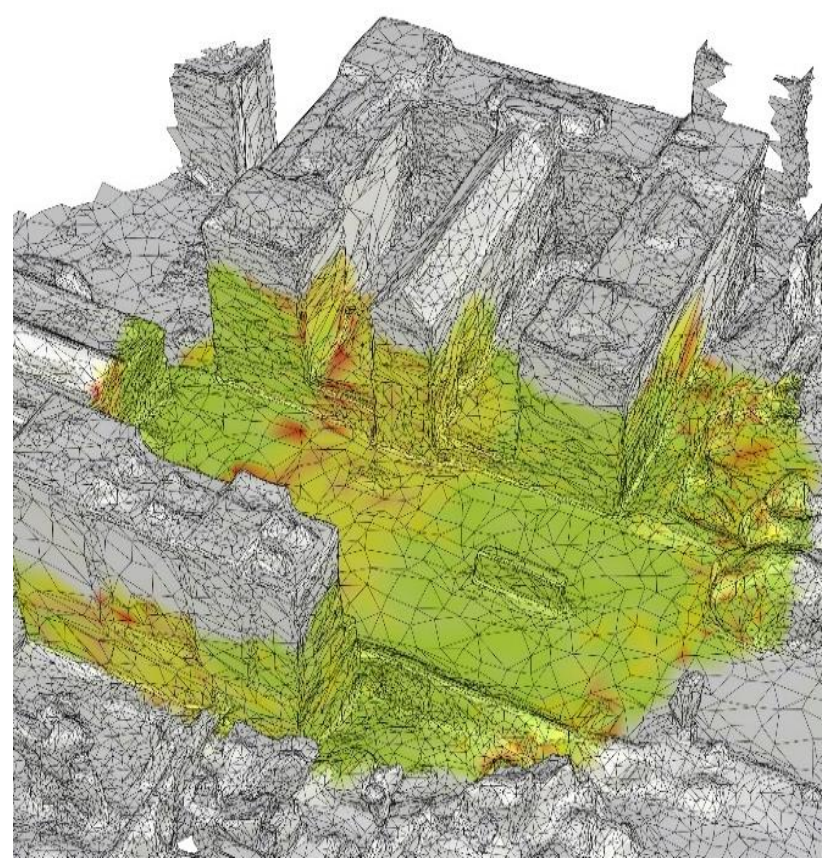

Figure 4 - The mesh built from the photo-modeling of Google Earth images with the RGB attribute.

\subsection{Means and Methods}

The innovative aspects that characterize the research are identifiable in the developed digital path. The relation between the psychology of vision and the representation, the analysis of the citizen behaviour in the public space, is develop using advanced digital tools and biosensors such as eye-tracking. This allows analysing analytically and scientifically the essential elements that impact on image and memory. It becomes essential and innovative, because the data connected with the Neuroheadset results, which guarantee to understand which part of the cerebral cortex is impacted by certain signals and in certain environments, giving analyses that can innovate the design criteria. The eye-track is an instrument composed of two cameras, one framing the observer's eye while the other records the surrounding environment. After a calibration and through an algorithm, it is possible to associate both the pupil's movements and where it stares the environment. In this way, it is possible to record which elements the observer looks at and where he focuses most. It allows identifying in an objective way what are the most perceived elements in a given environment, and which consequently characterize it (Crosby and Hermens, 2018; Dufresne et al., 2017; Q. Li et al., 2016; Pieters and Warlop, 1999; Santos et al., 2015, 2015; Schiessl et al., 2003; Weichbroth et al., 2016).

The EEG helmet is a device that through electrodes records in a non-invasive way 14 channels (AF3, F7, F3, FC5, T7, P7, O1, $\mathrm{O} 2, \mathrm{P} 8, \mathrm{~T} 8, \mathrm{FC} 6, \mathrm{~F} 4, \mathrm{~F} 8, \mathrm{AF} 4)$ of the human brain and through an algorithm, it transforms them into cognitive states in real time (Kim et al., 2018). This is functional to the analysis of the behaviours (Aspinall et al., 2015; Berka et al., 2004, n.d.; Boutani et al., n.d.; Chynal et al., 2016; Gevins et al., n.d.; Hunter et al., n.d.; Itil et al., n.d.; Mavros et al., 2012; Sharma et al., 2017; Yadava et al., 2017). In fact, the raw data collected concerning brain impulses are interpreted by algorithms related to the EEG helmets and transformed into six cognitive states: valence, arousal, stress, meditation, focus, engagement (Badcock et al., 2015, 2013; Kotowski et al., 2018).

In the developed path, the combined use of the data was obtained through the criteria inherent in the circumplex model (Jonathan Posner, James A. Russell, 2008), an interpretative model updated over the years (Jonathan Posner, James A. Russell, 2008; Wioleta, 2013) which allows tracing back to emotions using only the cognitive states of valence and arousal (Yik, Russell and Steiger, 2011). With the valence value as first polar coordinate and the arousal value as second polar coordinate, it is possible to obtain a point within the circumplex model that represents the emotion of the observer. These points are associated with a unique color vector for each combination, transcribed in the RGB color space.

At the base of the reflection is the data fusion (B. Li et al., 2016) that allows us to read what man is attracted from and what the effects of perception on man are. In addition to the EEG data, the geographical position in real time is acquired simultaneously at a regular interval of one second. Thanks to the timestamp, it was possible to synchronize the GPS and the EEG data.

The experimental path leads to gathering data on the position and cognitive states of several testers. It is therefore necessary to find a way to compare the emotions of the different testers based on the spatial position. Through an algorithm developed in the Grasshopper visual script language for the Nurbs environment of Rhinoceros, it is possible to import the csv data of the experiments containing synchronized coordinates and EEG data, to identify in which positions the observations were taken from contiguous and comparable points. The plan referred to the space intakes was then subdivided into a grid with a pitch of $6 \mathrm{~m} \times 6 \mathrm{~m}$, correlated to the data uncertainty in the hypothesis that the subject moves with a speed of 1 meter per second. The algorithm developed then identifies which experiments are comparable and it calculates the average of the EEG and GPS values belonging to the same cell. In this way, we obtain the average emotion of the observers in space, represented by the data and the color of the circumplex model.

The representation of the data is possible using as a basis a mesh of the territory (DEM) object of analysis. The mesh was obtained through a photo-modeling process starting from the digital data of Google Earth, selected with a route of extraction of highresolution photograms and reconstructed with specific software for the construction of models from photos in particular using (Agisoft Metashape). Juxtaposed to the mesh of the basic model is a vertex value consisting of a numerical attribute of the RGB color and therefore an expression of the circumplex model. 


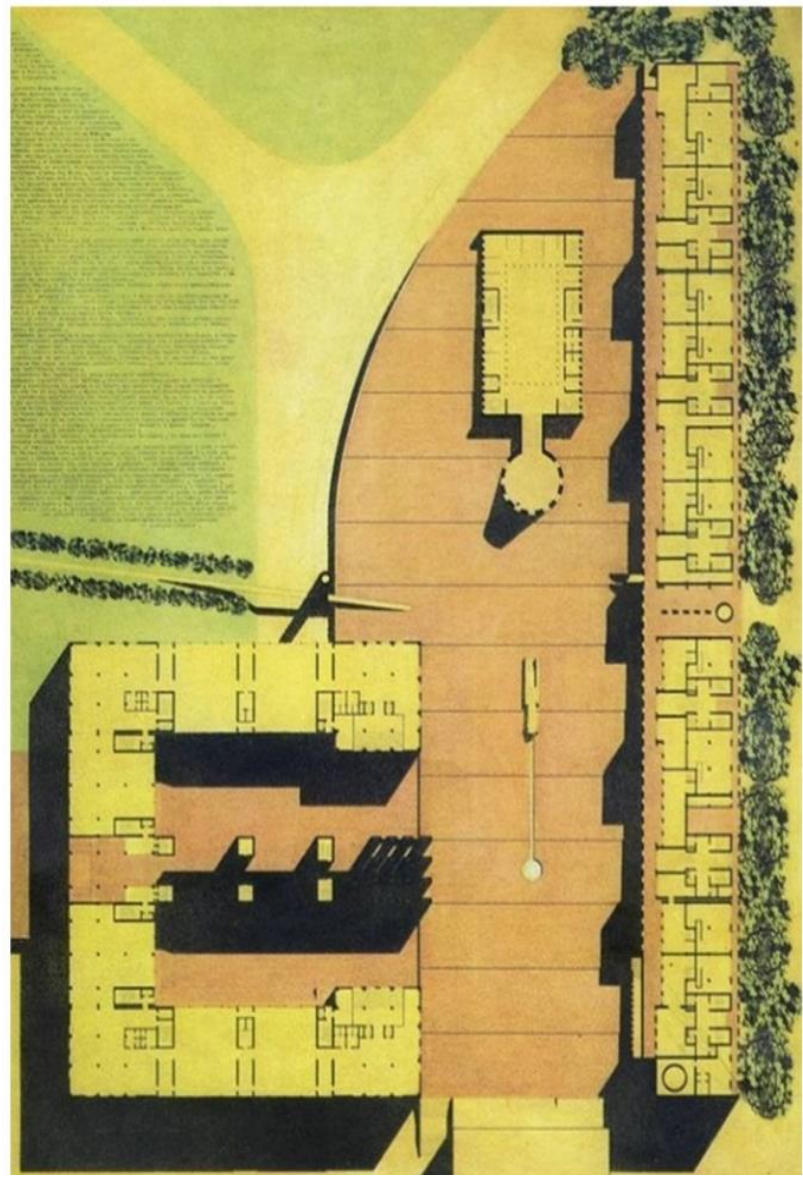

Figure 5- Original project of Aldo Rossi's square.
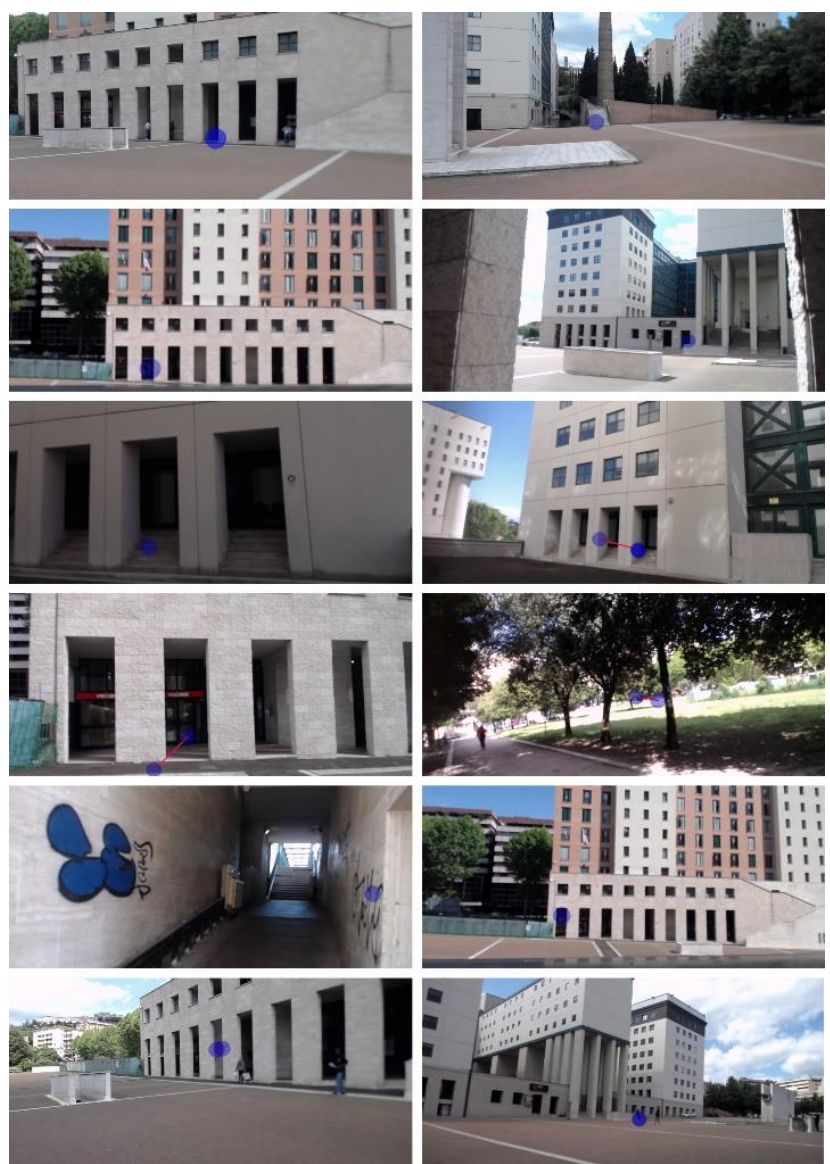

Figure 6 - Some frames of the recordings with Eye-Tracker in the current square. Circled in blue where the gaze rests, and in red the gaze rapid movement.

It is an area interpreted as dangerous, due to the failure to complete the architectural intervention, and on the other hand, to the same design choices of the famous architect Aldo Rossi (Rossi and Huet, 1984), linked to an idea of metaphysical architecture and stereometric forms marked by the rhythm of openings. It is then an area at the center of the debate, where one wonders if safety issues are linked to design choices.

Data acquisition took place by using EEG Emotiv Epoc +, EyeTrack Pupil and, for the geographical coordinates, a Samsung Gear S3.

There were 50 registrations and observers aged between 29 and 65 , of whom 26 women and 24 men.

The experimentation began on the west side of Piazza del Bacio, after which the observer was free to roam inside it and in the surrounding areas.

The acquired EEG RAW data were processed by Emotiv PRO and exported in CSV format with the average valence and arousal metrics in regular intervals of 10 second. To synchronize them with the coordinates recorded every second, the average value was calculated every 10 seconds. In this way, each data is synchronized according to the timestamp at intervals of 10 second.

From the results, it emerges that the areas near the arcades, which partially surround the square, generate a strong feeling of "alert" in the test participants. Furthermore, the entrance areas to the square are polar, this are two: northward through a green area, and southward by two large staircases, of which the one towards the station is more alerting, probably being known to testers the habit of dwelling on such stairs from unreliable subjects. As evidenced by the eye tracking, the arcades are characterized by 
The International Archives of the Photogrammetry, Remote Sensing and Spatial Information Sciences, Volume XLII-2/W15, 2019 27th CIPA International Symposium "Documenting the past for a better future”, 1-5 September 2019, Ávila, Spain

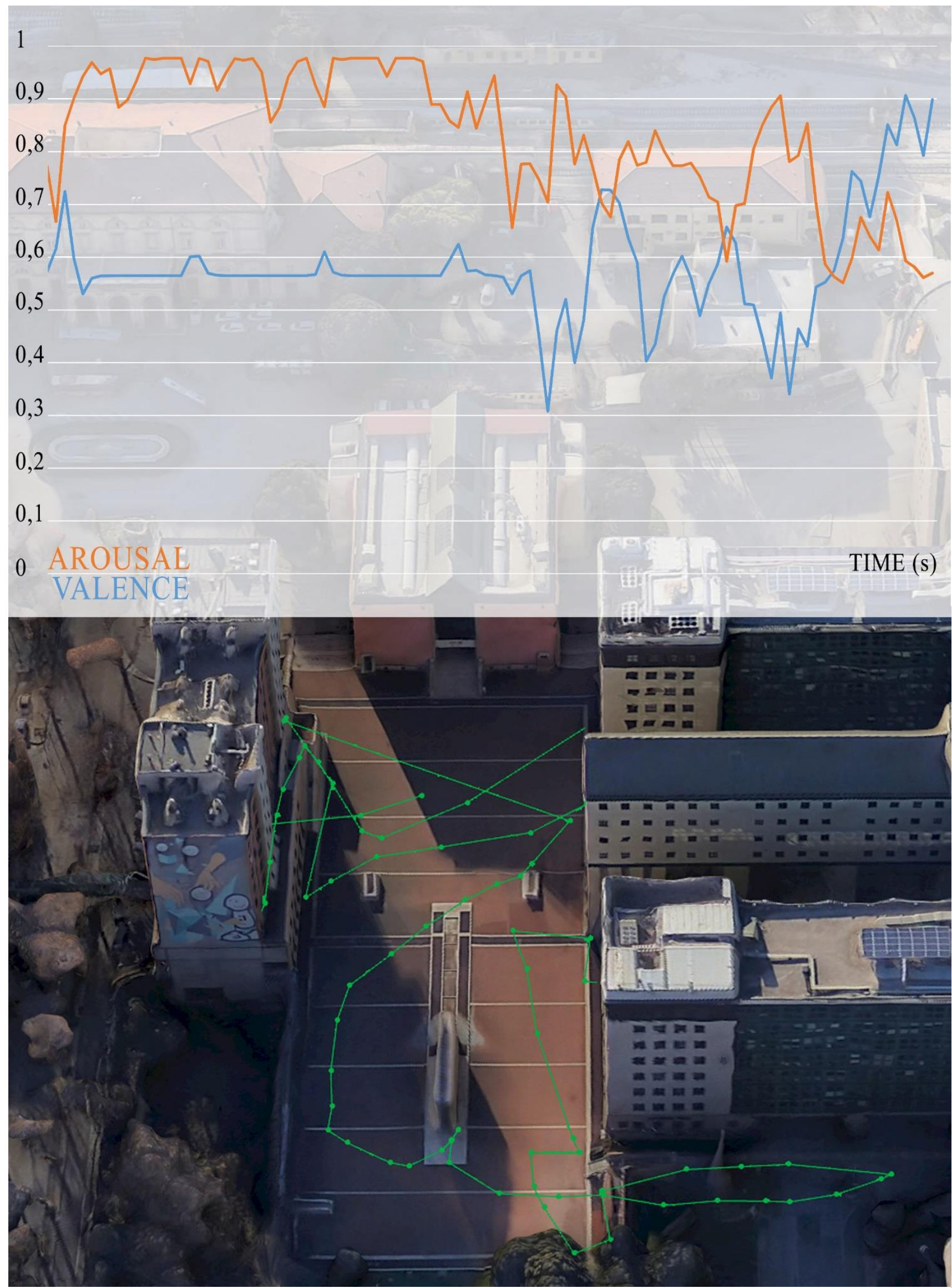

Figure 7 - Records referred to a tester concerning the Arousal and Valence values recorded in function of time and of location. 


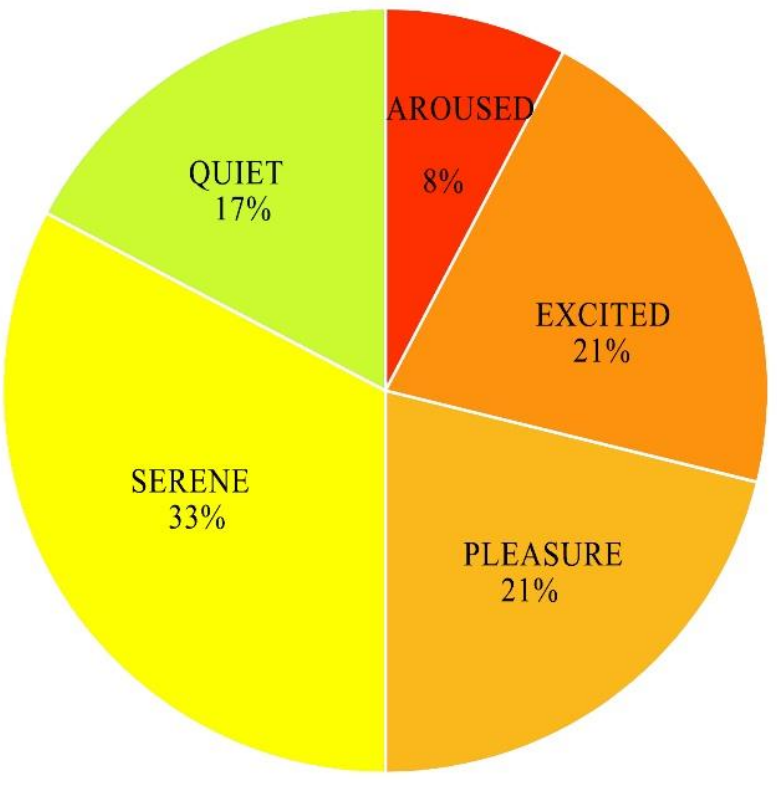

Figure 8 - Average emotional states in the square.

to the sense of insecurity. A slight slope, which implicitly characterizes an effort in the journey on one way and on the other it imposes an acceleration, marks the built square. This contrasts with the green area, which for the very qualities of its natural essence and probably because it is open and controllable, arouses relaxation and calm, emotions fragmented by a more turbulent excitement in the tree-screened borders. Analyzing data, it is possible to see the emotional state in the area, characterized by $29 \%$ of negative state, an important percentual considering the survey activity and a comparison with other experiences (Bianconi \& Filippucci, 2019b).

\section{CONCLUSION}

The integration of different instruments, to be innovate in the project also by improving their performances, may lead to a combined analysis understandable only if the data are analysed through an interdisciplinary reading. The proposal then has the aim of defining methodologies for collecting data. It also wants to define interdisciplinary interpretative criteria to understand what is analysed, arriving to considerations of synthesis to be poured into the metaprojective field, to then test possible improvement solutions in the concerned areas and empirically analyse their impact.

With an interdisciplinary approach, through new devices, it is possible to analyse what man sees, what emotion he feels, how the environment influences his emotional state implicitly, which are the places and the conditions that favour welfare.

Moreover, studying the public spaces means promoting a vision centred on man that involves the active involvement of the users, taking into account the specificity of the contexts in which they act as they "really are" and not as they "should be". The codesign is implicated in these studies, the discipline deals with the human factor in order to study how man acts in his environment, in order to promote a truly inclusive design aimed at making people who live in it feel at home, feeling the spaces as their own.

The digital then becomes a real tool of Computer Aids Design, with digital data used not only to show the visible but also to make visible what is implicit in the relation between man and the environment. It is then a useful methodology to verify operationally the sense of places, which really and analytically focuses on emotions and meanings, and which is definable as a concrete methodology to analyze not only the territory and the environment, but also the landscape, intended as a result of the path of perception.

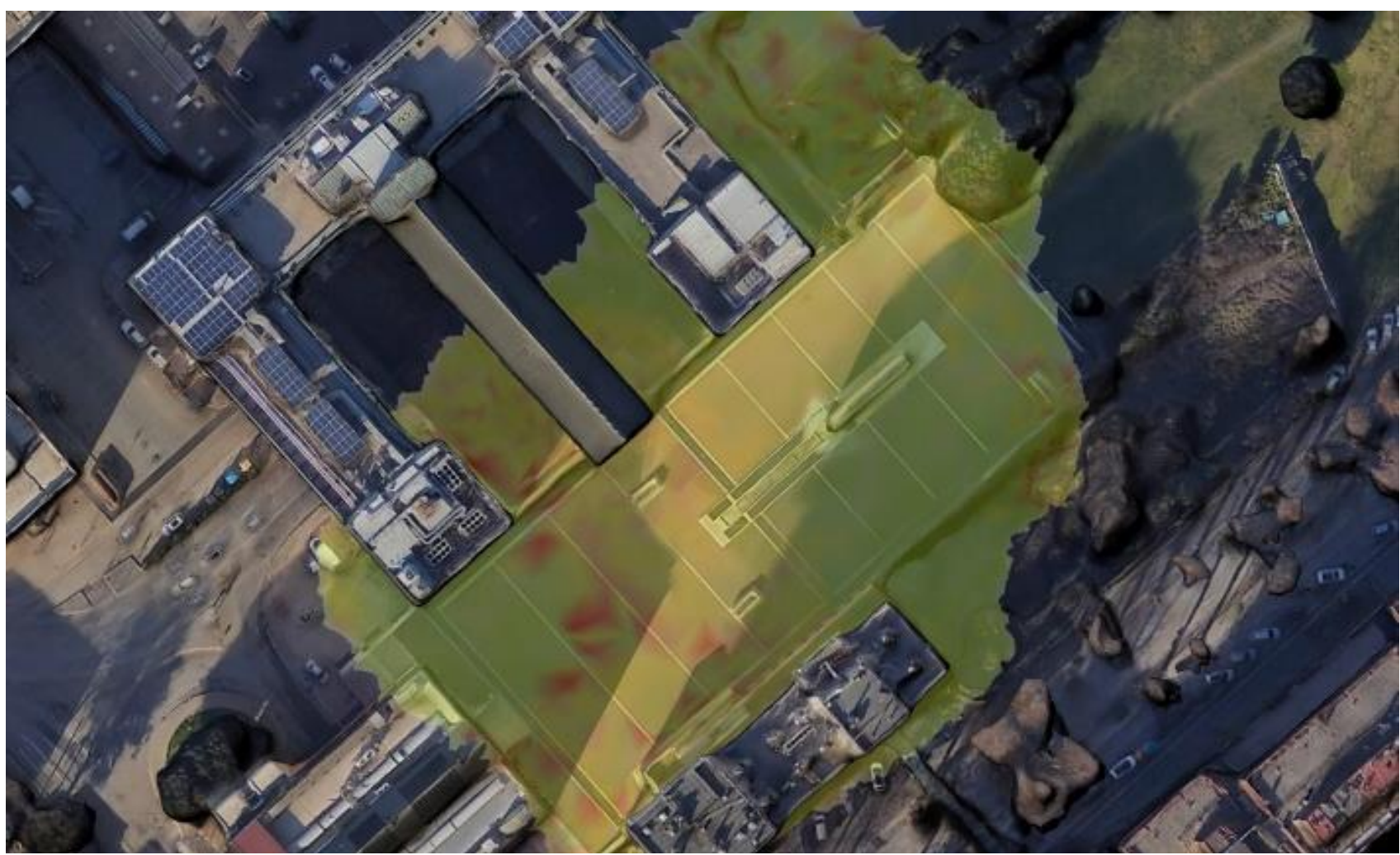

Figure 9- DEM in planimetric view with the addition of color attributes according to the EEG data related to the circumplex model. 


\section{REFERENCES}

Ancona, L., 1970. Dinamica della percezione. Mondadori, Milano.

Anderson, D.M., 2002. Build-to-order and mass customization: the ultimate supply chain management and lean manufacturing strategy for low-cost on-demand production without forecasts or inventory. CIM Press, Cambria.

Anderson, N.S., Norman, D.A., Draper, S.W., 2006. User Centered System Design: New Perspectives on HumanComputer Interaction. Am. J. Psychol., 101, 148. https://doi.org/10.2307/1422802

Appadurai, A., 1996. Modernity at large : cultural dimensions of globalization. University of Minnesota Press, Minneapolis.

Appleyard, D., Lynch, K., Myer, J.R., 1966. The View from the Road. Joint Center for Urban Studies of the Massachusetts Institute of Technology and Harvard University Press, Cambridge.

Arnheim, R., 1986. New essays on the psychology of art. University of California Press, Berkeley.

Arnheim, R., 1965. Art and visual perception: A psychology of the creative eye. Univresity of California Press, Los Angeles.

Aspinall, P., Mavros, P., Coyne, R., Roe, J., 2015. The urban brain: Analysing outdoor physical activity with mobile EEG. $\mathrm{Br}$. J. Sports Med., 49, 272-276. https://doi.org/10.1136/bjsports2012-091877

Badcock, N.A., Mousikou, P., Mahajan, Y., de Lissa, P., Thie, J., McArthur, G., 2013. Validation of the Emotiv EPOC ® EEG gaming system for measuring research quality auditory ERPs. PeerJ, 1, e38. https://doi.org/10.7717/peerj.38

Badcock, N.A., Preece, K.A., de Wit, B., Glenn, K., Fieder, N., Thie, J., McArthur, G., 2015. Validation of the Emotiv EPOC EEG system for research quality auditory event-related potentials in children. PeerJ, 3, e907. https://doi.org/10.7717/peerj.907

Badland, H., Pearce, J., 2019. Liveable for whom? Prospects of urban liveability to address health inequities. Soc. Sci. Med., https://doi.org/10.1016/j.socscimed.2019.05.001

Barthes, R., 1967. Semiologia e urbanistica. Op.cit., 9.

Bechtel, R.B., Churchman, A., 2002. Handbook of environmental psychology. J. Wiley \& Sons, New York.

Belardi, P., Bianconi, F., 2012. I AM A HOSPITAL. Dal wayfinding al waysharing per il miglioramento della percezione spaziale e dell'orientamento negli ospedali. Alinea Editrice, Firenze.

Berčík, J., Horská, E., Gálová, J., Margianti, E.S., 2016. Consumer neuroscience in practice: The impact of store atmosphere on consumer behavior. Period. Polytech. Soc. Manag. Sci. https://doi.org/10.3311/PPso.8715

Berka, C., Levendowski, D.J., Cvetinovic, M.M., Petrovic, M.M., Davis, G., Lumicao, M.N., Zivkovic, V.T., Popovic, M. V., Olmstead, R., 2004. Real-time analysis of EEG indexes of alertness, cognition, and memory acquired with a wireless EEG headset. Int. J. Hum. Comput. Interact., 17, 151-170. https://doi.org/10.1207/s15327590ijhc1702_3

Berrocal, J., Miranda, J., Garcia-Alonso, J., Mikkonen, T., Makitalo, N., Murillo, J.M., Canal, C., 2015. From the Internet of Things to the Internet of People. IEEE Internet Comput., 19, 40-47. https://doi.org/10.1109/mic.2015.24

Bianconi, Fabio., Filippucci, M., 2019. Landscape Lab. Drawing, Perception and Design for the Next Landscape Models. Springer, Cham.

Bianconi, Fabio, Filippucci, M., 2019. Visione e disegno . Percezione, rilievo e progetto per nuovi modelli di spazi urbani. Mondi e Modi Dell'abitare Per Una Sociologia Della Convivenza. Rubbettino, Soveria Mannelli (CZ), 81-104.

Bianconi, F., Filippucci, M. (eds.), 2018a. Il prossimo paesaggio. Realtà, rappresentazione, progetto. Gangemi, Roma.

Bianconi, F., Filippucci, M., 2018b. Rappresentazione, percezione, progetto. Il ruolo dell'Università per Perugia città smart. Rappresentazione Materiale/Immateriale - Drawing as (in) Tangible. Gangemi, Roma, 37-48.

Bianconi, F., Filippucci, M., 2017a. Codesign, Social Contracts, Environmental Citizenship. The Case Study of Umbrian Region's Atlas of Objectives and Lake Trasimeno Landscape Contract. Putting Tradition into Practice: Heritage, Place and Design. Proceedings of 5th INTBAU International Annual Event. Springer, 1432-1441.

Bianconi, F., Filippucci, M., 2017b. Il disegno degli olivi tra forma e luce. Le potenzialità analitiche della rappresentazione parametrica nell'interdisciplinarità della ricerca. Drawing form and light of olive trees. The analytic potentiality of parametric representation into the interdisciplinarity of research. Territori $e$ Frontiere Della Rappresentazione / Territories and Frontiers of Representation. Gangemi Editore, Roma, 439-450.

Bianconi, F., Filippucci, M., Felicini, N., 2019. Immersive wayfinding: virtual reconstruction and eye-tracking for orientation studies inside complex architecture. Isprs - Int. Arch. Photogramm. Remote Sens. Spat. Inf. Sci., XLII-2/W9, 143-150. https://doi.org/10.5194/isprs-archives-xlii-2-w9-143-2019

Boutani H., Ohsuga M., 2013, Applicability of the "Emotiv EEG Neuroheadset" as a user-friendly input interface. 2013 35th Annual International Conference of the IEEE Engineering in Medicine and Biology Society (EMBC). IEEE, https://doi.org/10.1109/EMBC.2013.6609758

Brandt, P.A., 2006. Form and Meaning in Art. Turner, M. (ed.), The Artful Mind. Cognitive Science and the Riddle of Human Creativity. Oxford University Press, Oxford, 171-188.

Buchanan, R., 2002. Human Dignity and Human Rights: Thoughts on the Principles of Human-Centered Design. Des. Issues, 17, 35-39. https://doi.org/10.1162/074793601750357178

Byrne, J., Newell, J., Wolch, J., 2014. Urban Green Space, Public Health, and Environmental Justice: The Challenge of Making Cities "Just Green Enough". Landscape Urban Plan., 234-244.

Cakir, A., 2011. The handbook of human-machine interaction a human centered design approach. Behav. Inf. Technol., 30, 867-868. https://doi.org/10.1080/0144929X.2011.603960 
Carmichael, L., 2019. Delivering Urban Health through Urban Planning and Design. Handbook of Global Urban Health. Routledge, $\quad$ London, 97-114. https://doi.org/10.4324/9781315465456-5

Castells, M., 2008. The new public sphere: Global civil Society, communication networks, and global governance. Ann. Am. Acad. Pol. Soc. Sci.. https://doi.org/10.1177/0002716207311877

Chynal, P., Sobecki, J., Rymarz, M., Kilijanska, B., 2016. Shopping behaviour analysis using eyetracking and EEG. Proc. - 2016 9th Int. Conf. Hum. Syst. Interact., 458-464. https://doi.org/10.1109/HSI.2016.7529674

Codeluppi, V., 2011. Il mito del consum-attore. Cultura $e$ Comunicazione. 2, 12-18.

Conti, M., Das, S.K., Bisdikian, C., Kumar, M., Ni, L.M., Passarella, A., Roussos, G., Tröster, G., Tsudik, G., Zambonelli, F., 2012. Looking ahead in pervasive computing: Challenges and opportunities in the era of cyberphysical convergence. Pervasive Mob. Comput., $\quad$ 8, 2-21. https://doi.org/10.1016/j.pmcj.2011.10.001

Conti, M., Passarella, A., Das, S.K., 2017. The Internet of People (IoP): A new wave in pervasive mobile computing. Pervasive Mob. Comput. https://doi.org/10.1016/j.pmcj.2017.07.009

Corburn, J., 2004. Confronting the challenges in reconnecting urban planning and public health. Am. J. Public Health, 94, 5416. https://doi.org/10.2105/AJPH.94.4.541

Coverley, M., 2018. Psychogeography. Oldcastle Books Ltd, Harpenden.

Crosby, F., Hermens, F., 2018. Does it look safe? An eye tracking study into the visual aspects of fear of crime. Q. J. Exp. Psychol. 174702181876920. https://doi.org/10.1177/1747021818769203

Cullen, G., 1961. Townscape. The Architectural Press, London.

Debord, G., 1958. Theory of the Dérive. Internationale Situationniste. 2, 50.

Dufresne, A., Courtemanche, F., Sénécal, S., Fredette, M., Léger, P.-M., Labonté-LeMoyne, É., 2017. Physiological heatmaps: a tool for visualizing users' emotional reactions. Multimed. Tools Appl., 77, 11547-11574. https://doi.org/10.1007/s11042-0175091-1

Ewing, R., Clemente, O., Neckerman, K.M., Purciel-Hill, M., Quinn, J.W., Rundle, A., 2013. Measuring Urban Design, Measuring Urban Design. Island Press: Washington https://doi.org/10.5822/978-1-61091-209-9

Filippucci, M., 2013. Disegno e figurazione, scrittura e oralità. L'immagine della città e il valore della percezione per la ricerca delle scienze della rappresentazione. Linee Di Ricerca Nell'area Del Disegno. Approfondimenti dalle Tesi Di Dottorato. Aracne, Roma, 300-308.

Filippucci, M., Rinchi, G., Brunori, A., Nasini, L., Regni, L., Proietti, P., 2016. Architectural modelling of an olive tree. Generative tools for the scientific visualization of morphology and radiation relationships. Ecol. Inform., 36, 84-93. https://doi.org/10.1016/j.ecoinf.2016.09.004
Florido, Al.M., Montero, F.R., Plaza, J.M.C., 2018. Robust 3D Visual Localization Based on RTABmaps, in: Garcia-Rodriguez, J. (Ed.), Advancements in Computer Vision and Image Processing. IGI Global, Hershey, 1-17.

Francis, J., Giles-Corti, B., Wood, L., Knuiman, M., 2012. Creating sense of community: The role of public space. $J$. Environ. Psychol. https://doi.org/10.1016/j.jenvp.2012.07.002

Friedman, Y., 1972. On Models of Utopias and Social Ecology. Leonardo 5.1, 37-41. https://doi.org/10.2307/1572470

Gaulon, C., Derec, C., Combriat, Tt., Marmottant, P., Elias, F., 2017. Sound and vision: visualization of music with a soap film. Eur. J. Phys., 38, 045804. https://doi.org/10.1088/13616404/aa7147

Gehl, J., 2011. Life Between Buildings. Island Press, Washington, https://doi.org/10.1126/science.1072994

Gehl, J., 2007. Public spaces for a changing public life. Open Space: People Space. Taylor \& Francis, London, 23-30. https://doi.org/10.4324/9780203961827

Gehl, J., Gemzøe, L., 2003. New city spaces, The Danish Architectural Press, Copenhagen.

Gehl, J., Svarre, B., 2013. How to study public life, How to Study Public Life. https://doi.org/10.5822/978-1-61091-525-0

Gevins, A., Howard, R., A Sandoval - US Patent 7, 551, 952, 2009, U., n.d. EEG electrode headset. Google Patents.

Gibson, J.J., 2014. The ecological approach to visual perception. Routledge, London.

Giraldi, J.D.M.E., De Souza, M.T., De Oliveira, J.H.C., Jordao, I.L.D.S., 2017. Neuromarketing applied to consumer behaviour: an integrative literature review between 2010 and 2015. Int. J. Bus. Forecast. Mark. Intell., 3, 270. https://doi.org/10.1504/ijbfmi.2017.10006047

Gogel, W.C., Tietz, J.D., 1977. Eye Fixation and Attention as Modifiers of Perceived Distance. Percept. Mot. Skills, 45, 343362. https://doi.org/10.2466/pms.1977.45.2.343

Goheen, P.G., 1998. Public space and the geography of the modern city. Prog. Hum. Geogr. https://doi.org/10.1191/030913298672729084

Gregory, R.L., 1998. Occhio e cervello : la psicologia del vedere. Cortina. Milano.

House, J.S., Landis, K.R., Umberson, D., Umberson, D., 1988. Social Relationships and Health. Science, 29, 241, 4865, 540545 .

Hunter, D., McCarraher, K., ... K.F.-U.P., 2000, U., n.d. Headset for EEG measurements. Google Patents.

Itil, T., E Eralp - US Patent 5, 357,957, 1994, undefined, n.d. Electrode assembly for EEG headset. Google Patents.

Jackson L, 2003. The relashionship of urban design to human health and condition. Landsc. Urban planning., 64, 191-200. 
Jencks, C., 1969. Meaning in architecture. The Cresset Press, London.

Jonathan Posner, James A. Russell, B.S.P., 2008. The circumplex model of affect. Dev Psychopathol., 17, 715-734.

Jordao, I.L.D.S., Souza, M.T. De, Oliveira, J.H.C. De, Giraldi, J.D.M.E., 2017. Neuromarketing applied to consumer behaviour: an integrative literature review between 2010 and 2015. Int. J. Bus. Forecast. Mark. Intell., 3, 270. https://doi.org/10.1504/ijbfmi.2017.085371

Kepes, G., Chiaia, F.R., 1990. Il linguaggio della visione, Immagine e consumo. Dedalo, Bari.

Kim, M., Cheon, S., Kang, Y., 2018. Use of Electroencephalography ( EEG ) for the Analysis of Emotional Perception and Fear to Nightscapes Sustainability 11, 1, 233. https://doi.org/10.20944/preprints201809.0461.v1

Konstantinos Tzoulasa, K.K., Vennc, S., Yli-Pelkonenc, V., Kaźmierczaka, A., Niemelac, J., Jamesa, P., 2007. Promoting ecosystem and human health in urban areas using Green Infrastructure: A literature review. Landsc. Urban Plan., 81, 167-178. https://doi.org/10.1016/j.landurbplan.2007.02.001

Kotowski, K., Stapor, K., Leski, J., Kotas, M., 2018. Validation of Emotiv EPOC+ for extracting ERP correlates of emotional face processing. Biocybern. Biomed. Eng., 38, 773-781. https://doi.org/10.1016/j.bbe.2018.06.006

Lahmiri, S., 2018. Neuromarketing Perspective of Consumer Choice. Applications of Neuroscience, 286-295. https://doi.org/10.4018/978-1-5225-5478-3.ch013

Larkham, P.J., Short, J.R., 2006. An Introduction to Urban Geography. Geogr. J., 152, 412. https://doi.org/10.2307/632833

Lee AC. Maheswaran R., Lee A.C.K., M.R., 2011. The health benefits of urban green. J. Public Health. 33, 212-222.

Leeuw, E. de, 1999. Healthy Cities: urban social entrepreneurship for health. Health Promot. Int., 14, 261-270. https://doi.org/10.1093/heapro/14.3.261

Li, B., Wang, Y., Wang, K., 2016. Data fusion and analysis techniques of neuromarketing. WIT Trans. Eng. Sci., 113, 396404. https://doi.org/10.2495/IWAMA150461

Li, Q., Huang, Z.J., Christianson, K., 2016. Visual attention toward tourism photographs with text: An eye-tracking study. Tour. Manag., $243-258$ https://doi.org/10.1016/j.tourman.2015.11.017

Lynch, K., 1984. Good city form. Harvard-MIT, Cambridge.

Lynch, K., 1960. The image of the city. Harvard-MIT , Cambridge.

Mondo, M.C., Fluehr, J.M., McKeon T., Branas C.C., 2018. Urban green space and its impact on human health. Int. J. Environ. Res. Public Health, 15. https://doi.org/10.3390/ijerph15030445

Maffei, L., 2007. I diversi sentieri della memoria e l'arte visiva. Pinotti, A., Lucignani, G. (eds.), Immagini Della Mente: Neuroscienze, Arte, Filosofia. Cortina Raffaello, Milano, 69-81.
Marewski, J.N., Gaissmaier, W., Gigerenzer, G., 2010. Good judgments do not require complex cognition. Cogn. Process,. 11, 103-121. https://doi.org/10.1007/s10339-009-0337-0

Mavros, P., Coyne, R., Roe, J., Aspinall, P., 2012. Engaging the Brain: Implications of mobile EEG for spatial representation. Proc. 30th eCAADe Conf., 2, 647-656. https://doi.org/10.1097/01.mol.0000226119.20307.2b

Meng, F., Zhang, W., 2012. A review of wayfinding and a new virtual reality system for wayfinding studies. Int. J. Serv. Oper. Informatics, $\quad 7, \quad 197-211$. https://doi.org/10.1504/ijsoi.2012.051399

Millennium Ecosystem Assessment, 2005. Ecosystems and Human Well-Being: Synthesis. Island Press, Washington.

Norberg-Schulz, C., 1992. Genius loci: paesaggio ambiente architettura. Electa, Firenze.

Oliveira, J.H.C. De, 2014. Neuromarketing and sustainability: challenges and opportunities for Latin America. Lat. Am. J. Manag. Sustain. $\quad$ Dev., $\quad 1, \quad 35$. https://doi.org/10.1504/lajmsd.2014.059779

Oliveira, J.H.C. De, Giraldi, J. de M.E., Jabbour, C.J.C., Netto, C.F., Betti, K.C.M., 2014. Improving business innovation and research through the application of neuromarketing with ethics: a framework. Int. J. Bus. Innov. Res., 9, 52. https://doi.org/10.1504/ijbir.2015.065953

Oliviera, J.H.C. de, Giraldi, J. de M.E., 2017. What is Neuromarketing? A Proposal for a Broader and more Accurate Definition. Glob. Bus. Manag. Res. An Int. Journal, 9, 19-29.

Onay, O., 2016. A Mathematical Approach to Neuromarketing: A Weapon - Target Assignment Model. Int. J. Acad. Res. Bus. Soc. Sci., 6. https://doi.org/10.6007/ijarbss/v6-i1/1986

Pallasmaa, J., 1994. Identity, intimacy and domicile. Notes on the phenomenology of home. Finish Archit. Rev., 1-16.

Panofsky, E., 1927. Die Perspektive als "symbolische Form." Vor. der Bibl. Warbg. XXII, 258-330.

Pentland, A. "Sandy," 2013. The data-driven society. Sci. Am., $309,78-83$

Pieters, R., Warlop, L., 1999. Visual attention during brand choice: The impact of time pressure and task motivation. In $t . J$. Res. Mark. 16, 1-16. https://doi.org/10.1016/S01678116(98)00022-6

Pinotti, A., Lucignani, G., 2007. Immagini della mente: neuroscienze, arte, filosofia. Raffaello Cortina Editore, Milano.

Rajah, R., Lim, V.K.G., 2018. Cyberloafing in the realm of IoPTS: Examining individual neutralization and organizational citizenship behavior. Simmers, C. A., \& Anandarajan, M. (Eds.). The Internet of People, Things and Services: Workplace Transformations. $\quad$ Routledge, London. 67-88. https://doi.org/10.4324/9781315182407

Ramachandran, V.S., 1990. Visual Perception in People and Machines,Blake, A., Troscianko, T. (Eds.), AI and the Eye. Wiley, London. 
Remondino, F., El-Hakim, S., Girardi, S., Rizzi, A., Benedetti, S., Gonzo, L., 2009. 3D Virtual reconstruction and visualization of complex architectures. The 3D-ARCH project. ISPRS Int. Work. 3D-ARCH XXXVIII-5/, 1-9.

Rossi, A., Huet, B., 1984. Tre citta : Perugia, Milano, Mantova. Electa, Firenze.

Rossi, A., Reinhart, F., Reichlin, B., Consolascio, E., 1976. La città analoga. Lotus, 13, 4-7.

Sanders, M.S., McCormick, E.J., 1987. Human factors in engineering and design, Mcgraw-Hill Book Company, New York. https://doi.org/10.1016/0169-8141(88)90028-5

Santos, R.D.O.J. dos, Oliveira, J.H.C. de, Rocha, J.B., Giraldi, J.D.M.E., 2015. Eye Tracking in Neuromarketing: A Research Agenda for Marketing Studies. Int. J. Psychol. Stud., 7. https://doi.org/10.5539/ijps.v7n1p32

Sarah Williams Goldhagen, 2017. Welcome to Your World. How the Built Environment Shapes Our Lives. HarperCollins, New York.

Schiessl, M., Duda, S., Thölke, A., Fischer, R., 2003. Eye Tracking and its Application in Usability and Media Research. MMI Interakt. -- Eye Track., 1, 41-50.

Schram-Bijkerk, D., Otte, P., Dirven, L., Breure, A.M., 2018. Indicators to support healthy urban gardening in urban management. Sci. Total Environ., 621, 863-871. https://doi.org/10.1016/j.scitotenv.2017.11.160

Schultz, N., 1987. On the Way to Figurative Architecture, Places 4.1. https://doi.org/10.5811/westjem.2011.5.6700

Settis, S., 2014. Azione popolare : cittadini per il bene comune. Einaudi, Milano.

Sharma, G., Kaushal, Y., Chandra, S., Singh, V., Mittal, A.P., Dutt, V., 2017. Influence of landmarks on wayfinding and brain connectivity in immersive virtual reality environment. Front. Psychol., 8. https://doi.org/10.3389/fpsyg.2017.01220

Sloan, C., 2015. Neuroeconomics and neuromarketing. Int. J. Bus. Manag. Econ. Res., 6, 133-136. Retrieved from http://ijbmer.com.

Srivastava, M., Abdelzaher, T., Szymanski, B., 2012. Humancentric sensing. Philos. Trans. R. Soc. A Math. Phys. Eng. Sci., 370, 176-197. https://doi.org/10.1098/rsta.2011.0244

Szondi, P., Mendelsohn, H., 1978. Hope in the Past: On Walter Benjamin. Crit. Inq., 4, 491-506. https://doi.org/10.1086/447949

Torelli, M., 1997. Il rango, il rito e l'immagine ; Alle origini della rappresentazione storica romana, Elemond-Electa, Roma.

Venturi, R.C., Scott Brown, D., Izenour, S., 1977. Learning from Las Vegas: the forgotten symbolism of architectural form. MIT Press, Cambridge.

Weichbroth, P., Redlarski, K., Garnik, I., 2016. Eye-tracking Web Usability Research. 016 Federated Conference on Computer Science and Information Systems (FedCSIS), IEEE. https://doi.org/10.15439/2016F127
Wioleta, S., 2013. Using physiological signals for emotion recognition. 2013 6th Int. Conf. Hum. Syst. Interact. HIS, 556561. https://doi.org/10.1109/HSI.2013.6577880

Yadava, M., Kumar, P., Saini, R., Roy, P.P., Prosad Dogra, D., 2017. Analysis of EEG signals and its application to neuromarketing. Multimed. Tools Appl., 76, 19087-19111. https://doi.org/10.1007/s11042-017-4580-6 